\title{
The Determinants of Enterprise Risk Management (ERM) Practices in Malaysian Public Listed Companies
}

\author{
Ahmad Rizal Razali, Ahmad Shukri Yazid, Izah Mohd Tahir* \\ Faculty of Business Management and Accountancy, University Sultan Zainal Abidin (UniSZA), Malaysia. \\ *izah@unisza.edu.my
}

\begin{abstract}
The objective of this study is to examine the determinants of Enterprise Risk Management (ERM) adoption in Malaysian Public Listed Companies (PLCs). The study focuses on ten industries from five hundred and seventy four Public Listed Companies in Malaysia for the period 2007. These ten industries include industrial products, trading/services, consumer products, properties, constructions, plantations, infrastructure projects, technology, hotels and mining. Logit regression approach will be employed, and a dummy variable equals one if companies adopt ERM and zero otherwise, is used as the dependent variable. Seven independent variables used are Size, Leverage, Profitability, International Diversification, Ownership, Chief Risk Officer and Turnover. The main results of this research is that companies with high turnover, hiring Chief Risk Officer and companies that are not diversified internationally are more likely to adopt ERM. Interestingly, Size, Leverage, Profitability, and Ownership are not significant determinants of ERM practices.
\end{abstract}

Keywords: Enterprise Risk Management, Public Listed Companies, Logit Regression, Malaysia

\section{Introduction}

The term Enterprise Risk Management (ERM) refers to enterprise-wide risk management, holistic risk management, corporate risk management, business risk management, integrated risk management and strategic risk management (D'Arcy, 2001; Manab et. al., 2007; Hoyt and Liebenberg, 2006; 2008). The Committee of Sponsoring Organization of the Treadway Commission (COSO) report (2004) defines “Enterprise Risk Management (ERM) as a process effected by an entity's board of directors, management and other personnel, applied in strategy-setting and across the enterprise, designed to identify potential events that may affect the entity, and manage risk to be within its risk appetite, to provide reasonable assurance regarding the achievement of entity objectives"

According to Lam (2000), ERM has seven components as follows:

- Corporate governance;

- Line management;

- Portfolio management;

- Risk transfer;

- Risk analytics;

- Data and technology resources;

- Stakeholder's management

ERM is therefore a systematically integrated and discipline approaches in managing risks within organizations to ensure firms achieve their objectives that are to maximize and create value to their stakeholders. ERM is used because of the benefits it brings to the organization. One of the benefits is to protect firms' organizational assets by its physical, customer, financial and employee/suppliers assets (Protiviti, 2006). This systematically process exists in planning, organizing, leading and controlling organizations activities in order to minimize firms' major risks such as financial, strategic and operational risks (Cassidy, 2005). Kleffner et. al., (2003) strongly argued that benefits of ERM should be looked on three factors. It is a coordinated and consistent approach to avoid major losses in handling overall risks, also better in integrating risk communication among departments. In addition, via ERM, companies may benefit the "company-wide philosophy", resulting in better understanding for everyone to achieve company's objective.

Furthermore, by applying ERM, companies especially at the board of directors level, may increase their risk awareness and extend more knowledge to get better results in decision making and for company's 
going concern process and finally to increase its value. A study by Yusuwan et. al., (2008) on Malaysian construction industry concluded that risk management still has a long way to go and that they are slowly accepting risk management as a management tool in assisting their business. Research in ERM especially in the Malaysian context is still considered scarce (Yazid, 2001). Therefore, this study is hoped in a way, fill the gap that exists. Our research provides a starting point for additional research into ERM in the public listed companies. Previous research on ERM takes the form of surveys. This study is valuable as a source of information on the characteristics of companies adopting ERM. The objective of the study is to examine the determinants of ERM adoption in Malaysian Public Listed Companies The results from this study would assist companies in identifying factors that determine the adoption of Enterprise Risk Management and to have an overview of the importance of ERM adoption.

\section{Literature Review}

Most of the larger companies are able to involve in ERM programs because they are facing wide risk area, more complex and large institutional size in supporting any cost that may occur in establishing ERM programs (Hoyt and Liebenberg, 2008). According to Lee (2000), companies need the right tools and conceptual framework to implement ERM. What the right tools mean is the appointment of Chief Risk Officer (CRO) itself. In another study by Beasley et. al., (2005) found that: (a) an appointment of CRO; (b) managerial support; (c) types of board directors; (d) size of firm; and (e) the existence of Big Four auditor have significance impact of firm to implement ERM. Meanwhile, Pagach and Warr (2007) found four main characteristics of firm that implement ERM. Their study show that firms using ERM has several characteristics as follows, (a) firm has more leveraged; (b) firm has incurred more volatile earnings; (c) firm has suffered poor stock markets performance; and (d) managerial influence characteristics inside of the firm. In addition, they found that there is a correlation between size and leverage, which influence firm to hire chief risk officer (CRO). Furthermore, empirical findings by Manab et. al., (2007) revealed that $58.80 \%$ of non-financial companies on ERM programs are led by internal audit department.

The findings by Desender (2007) had shown a different perspective - the board of directors with separation of CEO and chairman, plays a major role in determining characteristics of ERM programs. Even though this study is only focus on a single sample namely pharmaceutical industries, this results shows how importantly the composition of board of directors in determining characteristics of firm that involved in ERM activities. KPMG (2006) identified four major factors for US companies have exercised ERM: (a) the organization desire to reduce potential financial losses (68\%); (b) the organization desire to improve business performance (64\%); (c) due to the regulatory compliance requirements (58\%); and (d) the organization desire to increase risk accountability (53\%).

Price Waterhouse Coopers (2008) found five key factors that motivated firms to implement ERM in Finland as follows; (a) over 96 percent users want to adopt good business practice; (b) more than 81 percent due to corporate governance pressure; (c) 42 percent stated that it gives them a competitive advantage; and (d) more than 30 percent comes from regulatory pressure and also investment community pressure. Using hazard model, Pagach and Warr (2007) examined the characteristics of firms adopting ERM and find that firms that are more levered, have more volatile earnings and have exhibited poorer stock market performance are more likely to initiate an ERM program. A study by Yusuwan et. al., (2008) on the awareness among construction professional towards risk management, found that organizations such as constructions industry have implemented risk management in their operations although this is only on a small scale.

Previous research on ERM found some features of firms that implement the program. For example, Kleffner et. al., (2003) found size as measured by annual turnover is a key factor for larger companies to exercise ERM. Liebenberg and Hoyt (2003) found firms tend to practice ERM by appointing Chief Risk Officer (CRO). In addition, their study showed those firms which have financial leverage are most likely to hire CRO. Lam (2000) believed that chief risk officer (CRO) plays a major role in determining ERM programs. He urged that every industry lines should consider the function and the role of chief risk officer. This argument has been supported by Liebenberg and Hoyt (2003) and Pagach and Warr (2007) in determining the existence of CRO in major firms. Research done by Hussin et. al (2008) on a survey of 20 Malaysian Public Listed Companies found six factors that drove ERM as a value-added tool:

- A commitment and transparency from top management;

- Drives towards a more systematic management risks; 
- Strong involvement of executive leadership and their support;

- Perception and understanding for development of competency by companies itself;

- More and more education and training; and

- Culture-creation by companies

These "intangible insight" factors need most priority from top management level to bottom line staff within continuous programs of ERM.

\section{Data and Methodology}

Data: The samples of companies were categorized under business and economics segment and obtained from Osiris Database. This database covers all public listed companies worldwide including Malaysian companies. This data is provided by Bureau van Dijk. It is a comprehensive database of listed companies, bank and insurance companies around the world. It contains summary information, detailed financial information, ratings, scanned/digitalized report, market research and recent news of the companies.

Table 1 presents the breakdown of the sample used in this analysis, sorted by industry. It can be seen that Industrial Products provides us with the largest number of observations, followed by Trading/Services. Properties and Consumer Products are third and fourth largest sample. Companies in the mining industry are very small indeed. In terms of percentage, we find that Industrial Product represents about 26.48 percent, followed by Trading/Services (24.22 percent), Properties (14.98 percent), Consumer Products (14.63 percent), Constructions (7.49 percent), Plantations (6.62 percent), Technology (3.14 percent), Infrastructure Project (1.39 percent), Hotels ( 0.87 percent), and Mining Industry ( 0.17 percent).

In terms of companies adopting ERM from the sample in 2007, 157 or 29.7 percent had adopted ERM while 371 companies or 70.3 percent had not adopted ERM. From these results, it clearly shows that many companies are still not practising ERM even though from our analysis on the previous research, ERM programs are very important and beneficial. In terms of whether companies adopting ERM and hire Chief Risk Officer (CRO) or not, from the table, 12 companies or 7.10 percent hire CRO while 157 or 92.9 percent of ERM users do not hire CRO. Further, out of 528 companies, 248 or 46.97 percent are diversified internationally and 280 or 53 percent otherwise.

Table 1: Sample Companies

\begin{tabular}{lccccccc}
\hline Types of Companies & Sample & $\begin{array}{c}\text { ERM } \\
\text { user }\end{array}$ & $\begin{array}{c}\text { ERM } \\
\text { non-user }\end{array}$ & $\begin{array}{c}\text { ERM } \\
\text { with CRO }\end{array}$ & $\begin{array}{c}\text { ERM } \\
\text { without CRO }\end{array}$ & ID & No ID \\
\hline Consumer Products & 79 & 24 & 55 & 1 & 23 & 47 & 32 \\
Industrial Products & 139 & 47 & 92 & 2 & 45 & 79 & 60 \\
Constructions & 40 & 12 & 28 & 0 & 12 & 20 & 20 \\
Trading/Services & 124 & 40 & 84 & 3 & 37 & 56 & 68 \\
Infrastructure Project & 7 & 3 & 4 & 1 & 2 & 1 & 6 \\
Hotels & 4 & 1 & 3 & 0 & 1 & 0 & 4 \\
Properties & 79 & 21 & 58 & 3 & 18 & 20 & 59 \\
Plantations & 38 & 6 & 32 & 0 & 6 & 10 & 28 \\
Mining & 1 & 0 & 1 & 0 & 0 & 1 & 0 \\
Technology & 17 & 3 & 14 & 0 & 3 & 14 & 3 \\
Total & 528 & 157 & 371 & 12 & 157 & 248 & 280 \\
Total (in \%) & 100 & 29.7 & 70.3 & 7.1 & 92.3 & 46.9 & 53.0 \\
\hline
\end{tabular}

Note: $E R M=$ Enterprise Risk Management, $C R O=$ Chief Risk Officer, ID = International Diversification No $I D=$ No International Diversification

Source: OSIRIS database 
Table 2 presents the variables while Table 3 reports the descriptive statistics of the variables employed.

Table 2: Variables Used in the Logit Regression

\begin{tabular}{|c|c|c|}
\hline $\begin{array}{l}\text { Dependent Variable } \\
\text { ERM } \\
\text { Independent variables }\end{array}$ & \multicolumn{2}{|c|}{ Dummy variable 1 = company adopting ERM and 0 otherwise } \\
\hline SIZE & Total Assets (in ln) & Loans, investment and other earning assets \\
\hline LEV & Leverage & $\begin{array}{l}\text { Total liabilities divided by the market value of } \\
\text { equity }\end{array}$ \\
\hline ROA & Profitabili & Net income divided by total assets \\
\hline INTDIV & $\begin{array}{l}\text { International } \\
\text { Diversification }\end{array}$ & $\begin{array}{l}\text { Dummy variable } 1 \text { = company involved in } \\
\text { international diversification and } 0 \text { otherwise }\end{array}$ \\
\hline OWN & Ownership & Percentage of 30 largest shareholders \\
\hline CRO & Chief Risk Officer & $\begin{array}{l}\text { Dummy variable } 1 \text { = Chief Risk Officer is hired } \\
\text { and } 0 \text { otherwise }\end{array}$ \\
\hline TURNO & Turnover & Sales generated \\
\hline
\end{tabular}

Table 3: Descriptive Statistics of the Variables

\begin{tabular}{lccccc}
\hline \multicolumn{1}{c}{ Variable } & Mean & Median & Std. Dev & Minimum & Maximum \\
\hline ERM & 0.297 & 0 & 0.457 & 0 & 1 \\
SIZE & $15,692,204$ & 481,676 & $4,134,078$ & 52,025 & $44,221,300$ \\
LEV & 0.435 & 0.434 & 0.213 & 0.005 & 1.027 \\
ROA & 7.001 & 6.560 & 8.138 & $(39.610)$ & 44.950 \\
INTDIV & 0.451 & 0 & 0.498 & 0 & 1 \\
OWN & 64.602 & 68.38 & 20.187 & 7.460 & 99.99 \\
CRO & 0.019 & 0.0 & 0.136 & 0 & 1 \\
TURNO & 870,627 & 281,830 & $2,259,173$ & 544 & $29,604,700$ \\
\hline
\end{tabular}

Notes: Assets and turnover are in RM Million. Ownership is in percentage. We use natural log for assets and turnover.

Methodology: To capture the effects of ERM, we use the following logit regression:

$E R M_{j}=\beta_{0}+\beta_{1} S I Z E_{i}+\beta_{2} L E V_{i}+\beta_{3} R O A_{i}+\beta_{4} I N T D I V_{i}+\beta_{5} O W N_{i}+\beta_{6} C R O_{i}+\beta_{7} T U R N O_{i}+\varepsilon_{i}$

The dependent variable is a dummy variable equal to 1 for firms that adopt ERM and 0 otherwise.

\section{Findings}

Table 4 reports the results of the logit regression. It shows that variable SIZE is not significant in explaining ERM practices. This means that there is no relationship between SIZE (lnAsset) and ERM practices. This suggests that, size does not matter in choosing to adopt ERM practices. This is not surprising given the fact that Malaysian companies are still not aware of the importance of ERM though these companies are facing risks. Our study contradicts to that of Lienbenberg and Hoyt (2008) who found that size was related to the decision to implement ERM. The coefficients for TURNO are significant at the 5 percent level. This means that there is a relationship between turnover and ERM practices. It suggests that when a company is doing more aggressive sales, they earn more profit. Therefore, when their annual turnover is greater than cost, the company may support ERM programs. The coefficient for LEV is not significant in explaining ERM practices. It indicates that there is no relationship between Leverage and ERM, suggesting that companies with higher financial leverage are not likely to adopt ERM. Pagach and Warr (2007) found that firms that are more leveraged are more likely to initiate ERM programs. 
Table 4: Results of the Logit Regression Approach Dependent Variable is ERM

Logit Coefficients

\begin{tabular}{|c|c|c|c|c|}
\hline Independent Variables & Estimate & S.E & $p$-value & VIF Range \\
\hline Intercept & -3.380 & 1.161 & $0.004^{* * *}$ & \\
\hline SIZE & -0.091 & 0.135 & 0.502 & 2.539 \\
\hline TURNO & 0.275 & 0.134 & $0.040^{* * *}$ & 2.868 \\
\hline LEV & 0.034 & 0.566 & 0.952 & 1.454 \\
\hline ROA & -0.013 & 0.014 & 0.359 & 1.355 \\
\hline OWN & 0.007 & 0.005 & 0.231 & 1.223 \\
\hline CRO-1 & 3.756 & 1.531 & $0.014^{* * *}$ & 1.082 \\
\hline INTDIV-0 & -0.336 & 0.202 & $0.096^{*}$ & 1.070 \\
\hline \multicolumn{5}{|c|}{0.185} \\
\hline
\end{tabular}

${ }^{* * *}$ Significance at $1 \%,{ }^{* *}$ Significance at $5 \%,{ }^{*}$ Significance at $10 \%$

The coefficient for ROA is also not significant in determining ERM practices. It shows there is no relationship between ROA and ERM practices. It suggests to us that, it is possible for company to produce stable net income every year. When a company does not perform in terms of yearly sales, it also reflects their profits too. Therefore, the management may tend not to practice ERM because of this. The result for the variable of OWN is also not significant. It suggested that there is no relationship between Ownership and ERM practices meaning that regardless of the share of the companies, ERM seems not to be important. The coefficient for CRO is significant at the 5 percent level. This means there is a relationship between CRO and ERM practices. It suggests to us that the role for managing risks must be accelerated by Chief Risk Officer, which strongly supported by risk department and risk management committee. Therefore, companies that hire CRO tend to adopt ERM. This supports the research by Lam (2000) and Beasley et. al., (2005). Finally, the coefficient for dummy 0 for International Diversification shows significance result. This implies that companies that are not diversified internationally do not adopt ERM. It means that companies operating within the locality of Malaysia seem to adopt ERM practices. Hoyt and Liebenberg (2008) found that ERM users are large, more internationally and industrially diversified and less capital constrained than non-users.

\section{Conclusions}

The aim of this study is to examine the factors that determine the adoption of ERM practices among Malaysian Public Listed Companies for 2007. Logistic regression approach is adopted since the dependent variable that is ERM, is a dummy variable of which 1 represents companies adopting ERM and 0 otherwise. The results of this study show some interesting findings. ERM adoption is positively associated with high turnover and having a Chief Risk Officer. Companies that are large, internationally diversified, with high leverage, profitable and with ownership of 30 percent shares, appear not to adopt ERM. This is not surprising given the fact that the levels of awareness and understandings are still considered low among Malaysian public companies. It seems that companies that adopt ERM rely very much on the existence of Chief Risk Officer. This is consistent with the findings by Lam (2000); Liebenberg and Hoyt (2003); and Pagach and Warr (2007). As far as we are aware, this study is the first attempt made to examine the factors that determine the adoption of ERM among public listed firms in Malaysia. It is hoped that the study is beneficial to other researchers as well as practitioners. Evidence from this study clearly shows that by adopting ERM, companies will be able to manage their risks systematically. This study is without its limitations. Further research is needed to reconfirm our findings for example to include other relevant factors such as organizational structure of the companies and to include more years in the study. 


\section{References}

Beasley, M. S., Clune, R., \& Hermanson, D. R. (2005). Enterprise Risk Management : An Empirical Analysis of Factors Associated with the Extent of Implementation. Journal of Accounting \& Public Policy, 24(6), 521-531.

Cassidy, D. (2005). Enterprise Risk Management (ERM): A New Reality for Businesses. Employee Benefit Plan Review, 59(11), 29-31.

Committee of Sponsoring Organizations (COSO) (2004). Enterprise Risk Management-Intergrated Framework. COSO, New York.

D'Arcy, S. P. (2001). Enterprise Risk Management. Journal of Risk Management of Korea , 12 (1), 207-228.

Desender, K. A. (2007). The Influence of Board Composition on Enterprise Risk Management Implementation. Available at: http://papers.ssrn.com

Hoyt, R. E., \& Liebenberg, A. P. (2006). The Value of Enterprise Risk Management: Evidence from the U.S. Insurance Industry. Available

at: http://www.aria.org/meetings/2006papers/Hoyt_Liebenberg_ERM_070606.pdf

Hoyt, R. E., \& Liebenberg, A. P. (2008). The Value of Enterprise Risk Management: Evidence from the U.S. Insurance Industry. Available at: http://www.risknet.de

Hussin, R. M., Yazid, A. S. \& Razali, R. A. (2008). A Cross Sectional Study on Foreign Exchange Risk Management by Malaysian Manufacturers. Interntional Business Management, 2(2), 28-32.

Kleffner, A. E., Lee, R. B., \& McGannon, B. (2003). The Effect of Corporate Governance on the Use of Enterprise Risk Management : Evidence From Canada. Risk Management and Insurance Review , 6 (1), 53-73.

KPMG. (2006). Enterprise Risk Management in the United States : A 2006 Report Card. Available at: http://www.sdabocconi.it/files/kpmg_en_version_339QIKWY11U2ZKUEHUY51224057629.pdf

Lam, J. C. (2000). Enterprise-Wide Risk Management and the role of the Chief Risk Officer. Available at: http://www.erisk.com/learning/research/011_lamriskoff.pdf

Lee, C. R. (2000). Chief Risk Officer Stepping Up. Risk Management, 47 (9), 22-27.

Liebenberg, A. P., \& Hoyt, R. E. (2003). The Determinants of Enterprise Risk Management : Evidence From the Appointment of Chief Risk Officers. Risk Management and Insurance Review , 6 (1), 37-52.

Manab, N. A., Hussin, M. R., \& Kassim, I. (2007). Empirical Study on Theory and Practice of Enterprise-Wide Risk Management (EWRM) on Internal Auditing and Risk Managment Functions of Public Listed Companies in Malaysia. Available at: http/.rmi.nccu.edu.tw/apria/docs/Concurrent\%20IV/Session\%201/14707EWRM_APRIA_2007_ New.doc

Pagach, D., \& Warr, R. (2007). An Empirical Investigation of the Chraracteristics of Firms Adopting Enterprise Risk Management. Available at: http://papers.ssrn.com

Protiviti Inc. (2006). Guide to Enterprise Risk Management: Frequently Asked Questions. Available at: http://www.knowledgeleader.com/KnowledgeLeader/Content.nsf/dce93ca8c1f384d68625714 20036f06c/87e5c452010aadc9882571c00081a23c/\$FILE/ERM\%20FAQ\%20Guide.pdf

Yazid, A. S. (2001). Perceptions and Practices of Financial Risk Management in Malaysia. Unpublished Ph.D Tesis, Glasgow Caledonian University.

Yusuwan, N. M. Adnan, H., Omar, A. F. \& Jusoff, K. (2008). Clients' Perspectives of Risk Management Practice in Malaysian Construction Industry. Journal of Politics and Law. 1(3), 121-131. 